\title{
INFLUENCING FACTORS OF SMALL BREWERIES IN LATVIA
}

\author{
Lasma Licite, Arita Lukss \\ Latvia University of Agriculture \\ lasma.licite@llu.lv; aritalukss@inbox.lv
}

\begin{abstract}
Europe is the number two producer of beer worldwide. However, the quantity of beer sold in Latvia in the last decade did not increase considerably, and the average quantity of beer consumed per capita rose very slowly. Even though beer consumption was stable in Latvia, the quantity of beer supplied to the market was approximately three times greater than the quantity of the other kinds of alcoholic beverages combined, totalling about 15 million dekalitres. Besides, in recent years in Latvia the segment of craft beers tended to increase, which became increasingly popular in Western Europe and the number of small breweries sharply increased there. In Latvia, the number of small breweries increased at a slower pace, therefore, the research aim was to examine the factors influencing the development of small breweries in Latvia. The research found that most of the breweries in Latvia qualified for the status of small brewery, the output of which did not exceed 50000 dekalitres per year. Although small breweries produced craft beers, yet their performance and development were considerably influenced by the activity of the large breweries and the purchasing power of consumers. Small breweries positively influence the beer drinking traditions of Latvians, which can contribute to the stable development of the small breweries. Small breweries have their competitive advantages in the market, which is due to the quality and assortment of their products, as well as they perform extra economic activities that contribute to their recognition.
\end{abstract}

Key words: brewing industry, beer, factors, PEST, case study.

\section{Introduction}

In the alcoholic beverage domain, beer plays an important economic role, accounting for $78 \%$ of the worldwide alcoholic beverage market share (Euromonitor International, 2009, 2014). Therefore, the brewing industry and beer as a mass consumption product has been researched in the scientific literature from various aspects - from the consumer perspective (Aquilani et al., 2015; Giacalone et al., 2015; Donadini et al., 2016; Harasym \& Podeszwa, 2015), as an economic category (Nield \& Peacock, 1995), as a symbolic meaning (Mejlholm \& Martens, 2006) and in a functional sense (Guinard et al., 1998).

The beer category has been dominated for a long time by a single beer style: lager beer. But in the last decade a growing interest for craft and specialized beers has been noticed in several countries, including Latvia. In the past years craft beer sales have been growing faster than the dominant lager-style in countries with different beer tradition (Gomez-Corona et al., 2016a; Fastigi et al., 2015; Assobirra, 2014). In recent years in Latvia too, particularly the market of exclusive beers or the craft segment has been one of the fastest-growing ones. It is expected that this beer segment is going to expend until 2018, yet its growth pace will not be so fast (Does beer industry..., 2015). The growing interest in craft beers is strongly linked with small breweries because craft beer is usually made in small breweries, which is the research object of the paper.

In recent years in Latvia, the number of small breweries has considerably increased, and four large and 34 small breweries operated in the country in 2016. However, only approximately $30 \%$ of the total employees of the brewing industry were employed by small breweries, as most of them were employed by three largest breweries in Latvia (Aldaris, Cēsu alus and the Cido group's Lāčplēsis Brewery), which paid in taxes EUR 50 million a year (Does beer industry..., 2015). Even though a number of researchers have pointed out that it is not correct to compare large breweries with small ones, yet they are engaged in the same industry and the activities of large breweries affect the whole brewing industry, which was proved by a decrease in the market share of Aldaris in Latvia in 2014 that resulted in a considerable increase in the number of small breweries. In general, small breweries are affected by diverse political, social, economic and technological factors. The research aim is to examine the factors influencing the development of small breweries in Latvia. To achieve the aim, the following specific research tasks were set: 1) to determine the factors influencing small breweries in Latvia; 2) to analyse the performance of small breweries in Latvia.

\section{Materials and Methods}

The main research methods applied: monographic, descriptive, logical, comparative analysis, analysis and synthesis, induction and deduction. The methods of analysis and synthesis were used to study the problem elements and to synthesize coherence. The induction method was used for summarising individual facts in general statements, while the deduction method - for theoretical explanations and a logical synthesis of the empirical study. A graphical method was used for the statistical display of data.

A PEST analysis was performed to characterise the factors influencing small breweries. A PEST analysis can be used to survey a product, a company, an industry or a sector, a region or a country (Iglinski et al., 2016). 
This analysis provides more information about the political, economic, social and technological situation of the small breweries. Using a PEST analysis helps to understand various macro environmental factors that need to be taken into consideration when determining the decline or growth of a particular market.

To examine the experience of small breweries in Latvia, a case study was employed, as this method ensured a detailed examination of the situation (Stake, 1995; Yin, 2013; Bryman, 2008), including the performance of the small breweries.

A statistical data analysis was performed for the period 2010 - 2015, while a case study employed data for 2015. The research was based on the analysis of information published by the State Revenue Service's reports on trade in excised goods, Lursoft data and the scientific literature.

\section{Results and Discussion}

PEST analysis of the factors influencing small breweries

Political factors. In Latvia, the status of small brewery is granted in accordance with Cabinet Regulation No 956 'Procedures by which the Status of an Independent Small Brewery is Granted and the Rate of Excise Duty is Applied to Beer Produced by Independent Small Breweries' (adopted on 13 December 2005). After an application is submitted to the State Revenue Service, a small brewery is granted the status of an independent small brewery and a relevant certificate if its output of beer in the previous calendar year was less than 50000 hectolitres. Small breweries are taxed at a two times lower excise tax rate only for their first million litres of beer produced. Based on this criterion, almost all the breweries in Latvia are small ones; there are a number of breweries whose products are seen on the shelves of supermarkets, as the minimum quantity to be supplied is very large. This means that both those breweries whose output is actually low and those whose products are broadly available on the shelves of supermarkets qualify for the status of small brewery. It signifies that the term small brewery has a broad interpretation, and it is useful to introduce the status of micro-brewery in Latvia. This may be justified by the fact that those home breweries that want to enter the market and produce interesting products in respect to taste and sell the products in small quantities have to undergo the same bureaucratic procedures as those breweries whose products are available on the shelves of almost all supermarkets.

In view of the fact that beer is a food product, the operation of breweries is regulated by legal acts on food production, food safety and the handling of food: the Law on the Safety of Goods and Services (adopted on 7 April 2004), the Requirements for
Food Quality Schemes and the Procedures of their Introduction, Operation, Supervision and Control (adopted on 12 August 2004), the Law on the Supervision of the Handling of Food (adopted on 19 February 1998) and the Procedure of Training Persons Engaged in the Handling of Food in Food Hygiene (adopted on 29 September 2015). The measures prescribed by the legal acts often hinder production, as the risks referred to in the acts are not attributable to beer production.

As regards the effects of the legal acts on breweries, one has to note that the breweries are significantly influenced by the legal acts that regulate the promotion of a product in the market, including the Law on Electronic Mass Media (adopted on 12 July 2010), which sets restrictions on audio and visual commercial advertising with regard to alcoholic beverages. Section 5 of the Advertising Law (adopted on 20 December 1999) provides that it is prohibited to use children in advertising alcoholic beverages as well as address such advertisements to children. However, the greatest restrictions on advertising and promoting alcoholic beverages are set by Sections 10 and 11 of the Handling of Alcoholic Beverages Law (adopted on 22 April 2004), which strictly limit the information included in alcoholic beverage advertisements and set general restrictions on advertising.

Economic factors. The brewing industry is considerably influenced by the number of competitors and their activity in the market. Four large breweries prevail in Latvia's brewing industry, and there are 34 breweries that are granted the status of small brewery. According to the State Revenue Service reports on trade in excised goods, the largest numbers of founded small breweries (since 1992 when the first brewery was founded in Latvia) have been reported in 2014 and 2015, which was affected by the fact that the facility of Aldaris in Latvia was partially closed in 2014. Before it, Aldaris had a domestic market share of more than $30 \%$, yet in 2014 the enterprise changed its strategy and moved the production of the cheapest beers to other Carlsberg Group facilities, retaining the production of exclusive beers in Latvia. Consequently, the market was entered by a number of new small breweries, thereby increasing the production and consumption of exclusive sorts of beer.

One can conclude that competition in the brewing industry may be viewed as positive, as it contributes to the diversity and quality of the products. In terms of quantity, small breweries cannot and directly do not compete with large ones, yet they seek to focus on unusual tastes and high quality, which is an essential determinant factor for consumers. According to scientific research studies too, consumers are paying more attention to quality and local production (Mejlholm \& Martens, 2006). 
According to the State Revenue Service reports on trade in excised goods, almost half of small breweries were concentrated in Riga region (12), which may be explained by the fact that the purchasing power of Riga region residents was higher as well as tourism was more developed in Riga. This means that the purchasing power and standard of living of the population can significantly influence the situation in the brewing industry, as the price of products produced by small breweries, compared with large ones, is higher. A market study conducted by the brewery Aldaris and independent experts "Does the beer industry have a future in Latvia" forecasts that in the nearest years the beer industry in Latvia is going to stagnate with the market size decreasing by $2.6 \%$ until 2018; however, if the standard of living rises, consumers increasingly prefer higher quality beers (Does beer industry..., 2015).

At the initial phase of development of small breweries, their availability of finances is limited, as equipment for beer production is not cheap, and banks are reluctant to finance this segment and it is difficult for alcohol producers compared with other food sector participants to acquire European funding.

Social factors. Although food choices do not change fast (Riet et al., 2011), food habits can evolve (Gomez-Corona et al., 2016). Nowadays, individuals improve their understanding of the culture of tasting beers, traditions as well as matching beer to food. Individuals increasingly comprehend and appreciate new and interesting tastes. Such a trend stimulates beer makers to experiment with new tastes and create new, exclusive products. This may be considered to be an advantage of small breweries, compared with large ones, as the small breweries can offer an exclusive beer produced in small quantities, creating a feeling that there is no overproduction in the market. Besides, as found by scientists, individuals aged 21-30 are interested in exploring new beer tastes and willing to pay higher prices (Ascher, 2012; Brager \& Greco,
2011). It means that the demand for beer is affected by beer tastes and quality, which become a more essential factor than the price. At the same time, however, there are opposite opinions, i.e. the market study of the brewery Aldaris and independent experts found that in Latvia only $17 \%$ of all craft beer consumers were ready to try anything new, sometimes even something untypical of the classical understanding of beer. In Latvia's segment of classical craft beers, approximately 90 sorts of beers intensively compete for a quite small number of beer enjoyers. The market study showed that in the nearest three years, in terms of value, the segment of economic and strong beers would considerably decrease $(-11.5 \%)$, the segment of Premium beers would slightly decrease or remain the same $(-1 \%)$, while the segment of medium price category $(+15.5 \%)$ and craft beers $(+12 \%)$ would considerably increase, which would be affected by consumer behaviours and consumption traditions (Does beer industry..., 2015).

One can conclude that beer traditions and beer drinking culture and the diversity of beer tastes, in general, contribute to the demand for products of small breweries (Gomez-Corona et al., 2016a; Gomez-Corona et al., 2016b). It is evidenced by the fact that beer is the most produced and consumed alcoholic beverage in Latvia. The quantity of beer supplied to the market is about three times greater than the quantity of all the other alcoholic beverages combined. In the period 2011 - 2015, the consumption of alcoholic beverages has not considerably changed, totalling about 15 million dekalitres a year (Figure 1).

The indicator 'beer supplied to the market in Latvia' shows the quantity of beer produced in Latvia and imported from other countries that was supplied to the market in Latvia after the excise tax being paid. One can find that beer accounts for about $75 \%$ of the total consumption of alcoholic beverages in Latvia. Even though the quantity of beer supplied to the

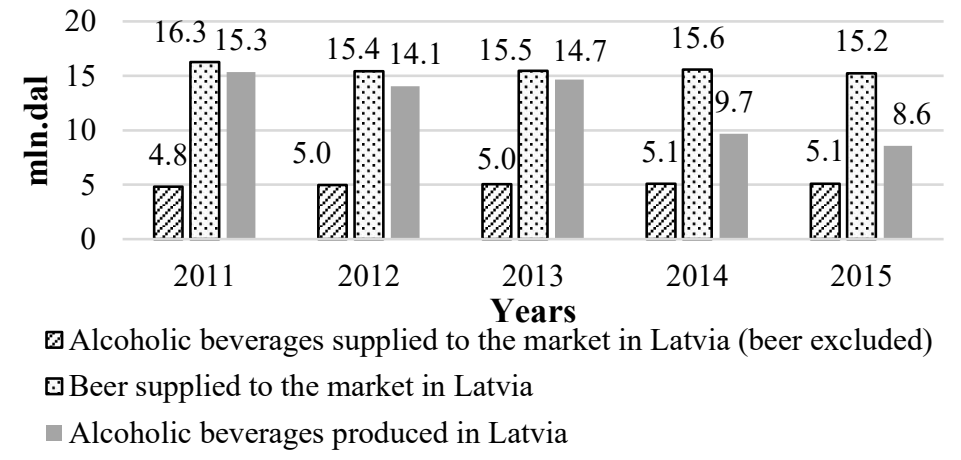

Source: authors' construction based on SRS reports on trade in excised goods.

Figure 1. Alcoholic beverages consumed in Latvia in 2011 - 2015, mln. Dal. 
market in Latvia has not significantly changed, due to the above-mentioned situation with Aldaris the output of beer has considerably changed in Latvia, which once more confirms the large market share of Aldaris in Latvia. Compared with 2013, the output of beer in Latvia in 2014 declined by 4.99 million dekalitres or $34.01 \%$. In 2015 compared with 2014 , too, the output of beer decreased in Latvia - by 1.12 million dekalitres or $11.57 \%$. During two years after Aldaris partially closed its facility in Latvia, the output of beer in the country decreased by approximately $45 \%$ or 6.11 million dekalitres.

The development of small breweries was affected by the trend, which was observed in recent years, to support domestically produced products, which could positively contribute to the turnover of small breweries.
Technological factors. Technological progress as a whole positively affects the common environment in which small breweries operate. The technological development of beer production at large breweries means that it is possible to modernise the production process even more and produce the beer in larger quantities as well as to provide an expected quality of the product. Such a way of development, on the one hand, would increase the difference between industrially produced beer and the beer produced by small breweries, which would, in the eyes of consumers, assign an even higher value to the latter, as the beer produced by small breweries reminds and, in relation to production, is very similar to homemade beer. However, on the other hand, technological development and the introduction of innovations at small breweries promote the creation of new products

PEST analysis of the beer industry in Latvia

Table 1

\begin{tabular}{|c|c|c|c|c|}
\hline \multirow{2}{*}{\multicolumn{2}{|c|}{ Factors }} & \multicolumn{2}{|c|}{$\begin{array}{l}\text { Factor effects on the } \\
\text { situation }\end{array}$} & \multirow{2}{*}{ Effects created by factors } \\
\hline & & $\begin{array}{c}++ \\
\text { (positive) }\end{array}$ & $\begin{array}{c}- \\
\text { (negative) }\end{array}$ & \\
\hline \multirow{3}{*}{ 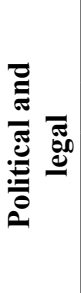 } & $\begin{array}{l}\text { Acquiring the status } \\
\text { of small brewery }\end{array}$ & \multicolumn{2}{|c|}{ effects } & \multirow{3}{*}{$\begin{array}{l}\text { - The term small brewery is widely interpreted in Latvia, as } \\
\text { those home producers that want to enter the market and sell their } \\
\text { products in small quantities have to undergo the same bureaucratic } \\
\text { procedures as the breweries supplying their products to the market } \\
\text { in large quantities. } \\
\text { - Excise tax relief is applied to small breweries. } \\
\text { - Advertising and distributing alcoholic beverages are limited. }\end{array}$} \\
\hline & Excise tax & effect & & \\
\hline & $\begin{array}{l}\text { Legal documents } \\
\text { limiting the } \\
\text { promotion of } \\
\text { products }\end{array}$ & & effect & \\
\hline \multirow{3}{*}{ 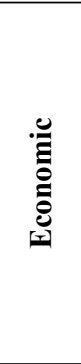 } & Competition & \multicolumn{2}{|c|}{ significant effects } & \multirow{2}{*}{$\begin{array}{l}\text { - The more large breweries are in the market, the more saturated } \\
\text { the market is. However, at the same time, competition is viewed as } \\
\text { positive, as it contributes to the diversity and quality of products. } \\
\text { - The price of products of small breweries is higher than that of } \\
\text { large breweries. Therefore, with the standard of living rising, } \\
\text { consumers will increasingly prefer higher quality beer. }\end{array}$} \\
\hline & $\begin{array}{l}\text { Purchasing power } \\
\text { and standard } \\
\text { of living of the } \\
\text { population }\end{array}$ & \multicolumn{2}{|c|}{ significant effects } & \\
\hline & $\begin{array}{l}\text { Availability of } \\
\text { finances }\end{array}$ & & effect & $\begin{array}{l}\text { The availability of finances to buy equipment is limited, as banks } \\
\text { are reluctant to finance this segment and it is difficult for alcohol } \\
\text { producers to acquire European funding. }\end{array}$ \\
\hline \multirow{3}{*}{ 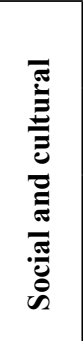 } & $\begin{array}{l}\text { Beer drinking } \\
\text { tradition }\end{array}$ & effect & & \multirow{3}{*}{$\begin{array}{l}\text { - Strong beer drinking traditions in summer and during the } \\
\text { midsummer festivities increase the consumption of beer. } \\
\text { - The wish of consumers to taste new products encourages } \\
\text { producers to consider expansion and broadening the assortment. } \\
\text { However, a lot of consumers are not ready to experiment with beer } \\
\text { tastes. } \\
\text { - Support for domestic products can positively influence the sales } \\
\text { of small breweries. }\end{array}$} \\
\hline & $\begin{array}{l}\text { Demand for new } \\
\text { tastes }\end{array}$ & \multicolumn{2}{|c|}{ significant effects } & \\
\hline & $\begin{array}{l}\text { Support for } \\
\text { products produced } \\
\text { in Latvia }\end{array}$ & effect & & \\
\hline 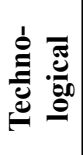 & $\begin{array}{l}\text { Progress in } \\
\text { production } \\
\text { technology and } \\
\text { innovation }\end{array}$ & effect & & $\begin{array}{l}\text { Technological progress and innovations introduced by small } \\
\text { breweries contribute to the development of new products. }\end{array}$ \\
\hline
\end{tabular}

Source: authors' construction. 
Economic performance characteristics of the enterprises selected for the case study in 2015

\begin{tabular}{|c|c|c|c|c|}
\hline Indicators & 'ECOS' Ltd & $\begin{array}{c}\text { 'Odzienas } \\
\text { Pilsbrūzis' Ltd }\end{array}$ & $\begin{array}{c}\text { 'Madonas Alus } \\
\text { Darītava' Ltd }\end{array}$ & $\begin{array}{c}\text { 'Raiskuma labumu } \\
\text { darītava' Ltd }\end{array}$ \\
\hline Net turnover, EUR & 29973.00 & 6427.00 & 30331.00 & 42774.00 \\
\hline Excise tax paid, EUR & 1825.00 & 126.00 & 2062.00 & 1216.00 \\
\hline Net revenue, EUR & -4235.00 & 39308.00 & -26359.00 & 4735.00 \\
\hline $\begin{array}{c}\text { Total tax revenue paid into the } \\
\text { consolidated government budget, } \\
\text { thou. EUR }\end{array}$ & 2.59 & -3.21 & 2.81 & -5.98 \\
\hline Lursoft rating & 1.3 & 2.9 & 2.2 & 2.7 \\
\hline
\end{tabular}

Source: authors' construction based on Lursoft data and enterprise annual reports.

that would allow fulfilling the wishes of other consumers.

A PEST analysis of the factors influencing the performance of small breweries is presented in Table 1.

\section{Performance of small breweries in Latvia}

In Latvia, every small brewery has a different history and production technology, different product specifics and packaging. Some small breweries produce also other kinds of products or services. A case study was done to better understand the experience of small breweries in Latvia. The case study selected four small breweries: 'Odzienas Pilsbrūzis' Ltd, 'Madonas Alus Darītava' Ltd, 'ECOS' Ltd and 'Raiskuma labumu daritava' Ltd to compare them according to the same criteria.

'Odzienas Pilsbrūzis' Ltd is a producer of beer and kvass located by the Odziena manor house in Plavinas municipality. Its advantage, compared with many other small breweries, is that it offers a number of halls for holding social events in the adjacent manor complex and a guest house with nine rooms for staying overnight. The enterprise is engaged in the production of a non-alcoholic beverage - kvass.

'ECOS' Ltd was registered in 2006 and was a wholesale intermediary for a broad assortment of goods until the brewery was built in 2014. The brewery produces 'Bursh' beer, which has become popular and has been in demand in Plavinas municipality, in its vicinity and in Riga region within two years after being on the market.

'Madonas Alus Darītava' Ltd produces 'Baudalu' beer in the centre of Madona town, and earned appreciation from industry professionals for the successful entry into the market and recognition in the brewing industry in 2016. At many shopping places, 'Baudalu' beer is placed along with 'Bursh' beer. The products of both 'ECOS' Ltd and 'Madonas Alus Darītava' Ltd took part in the project Latvian Craft Beer.
'Raiskuma labumu darītava' Ltd began producing its product in February of 2015, yet its recognition was earned within a short time. 'Raiskuma labumu darītava' Ltd also produces bread baked in an oven and smoked meat.

To perform an in-depth examination of the brewing industry, it is important to analyse the economic performance indicators of the enterprises selected for the case study. Since the first year for which data are available for all the breweries is 2015 , the authors particularly analysed the indicators for this year in order to better comprehend the financial situation in the small breweries (Table 2).

In 2015, the largest net turnover was reported by 'Raiskuma labumu darītava' Ltd, which may be explained by the diverse activity of the enterprise, as it produced three different products. The smallest net turnover was posted by 'Odzienas Pilsbrūzis' Ltd, which may be explained by the specifics of the enterprise - it was less engaged in the production of products, as its key occupation was associated with the rental of premises. Even though 'Raiskuma labumu daritava' Ltd began selling its products only in 2015 , its net turnover was $142 \%$ higher than that of 'ECOS' Ltd, which may be explained by its broader assortment.

The excise tax paid is one of the indicators that indicates the output of beer by an enterprise, as all the breweries are granted the status of an independent small brewery, and their payments for every 1001 of beer are equal. Based on this indicator, one can identify which breweries focus on beer production ('Madonas Alus Darītava' Ltd and 'ECOS' Ltd) and which are engaged in extra economic activities ('Odzienas Pilsbrūzis' Ltd and 'Raiskuma labumu daritava' Ltd). Their extra economic activities are indicated by the fact that they have a high net turnover ('Raiskuma labumu darìtava' Ltd) and net revenue ('Odzienas Pilsbrūzis' Ltd and 'Raiskuma labumu darītava' Ltd) despite their small amounts of excise tax paid (i.e. a small quantity of beer produced). As told in an interview with the manager of 
the 'Bursh' brewery, Mārtiņs Dagisis, 'even though the number of breweries has considerably risen in recent years, this niche is still free and there would be a place for at least the same number of small breweries. The most important thing is to create a tasty product; maybe there is no big need to seek differences from other products. At present, we produce only two sorts of beer and do not intend to expand the assortment'. He noted that they plan to engage in tourism activities too in future, using the potential of the location of the brewery $-\mathrm{a}$ nice farmstead. This may be justified by economic considerations, i.e. it is possible to enhance the competitiveness of small breweries by engaging in an extra economic activity.

The case study showed that 'Madonas Alus Darītava' Ltd and 'ECOS' Ltd suffered losses. Their financial reports revealed that 'ECOS' Ltd succeeded in reducing its losses, compared with 2014 , by $43 \%$, whereas 'Madonas Alus Darītava' Ltd had a 30\% increase in its losses, compared with the previous year. The analysis of the increasing losses showed that the other production costs considerably rose during that year, which was due to selling its fixed assets. That is why the losses of 'ECOS' Ltd may be considered a positive fact, whereas the increasing losses of 'Madonas Alus Darītava' Ltd may not be linked with a deterioration in its economic performance.

A Lursoft rating is calculated employing six financial performance indicators: solvency, profit before taxes, liquidity, increase in turnover, return on equity and liabilities. The overall rating of an enterprise is an arithmetic mean between a rating in its industry and a rating among all the enterprises in the country. According to Lursoft, 'ECOS' Ltd had the lowest rating, which may be explained by the financial performance indicators that were not taken into account in the calculations done by Lursoft, as a high weight in a rating was assigned to the enterprise's solvency, profit before taxes and liquidity ratio. Given all the financial performance indicators of the enterprise, one can conclude that none of the above-mentioned indicators included in the rating was positive for 'ECOS' Ltd, and the economic activity of the enterprise was unprofitable; therefore, the rating score was low. In contrast, 'Odzienas Pilsbrūzis' Ltd and 'Raiskuma labumu darītava' Ltd had the highest Lursoft ratings, which indicated the positive effects of their extra economic activities on their financial performance.

Given the enterprise analysis performed within the case study, further in the research, the competitiveness of the small breweries was compared according to subjectively selected key factors and their significance (Table 3). Only the factors with a weight ranging from 0.15 (less significant) to 0.3 (the most significant) were selected from the distribution of the key factors by significance. The factors of enterprise competitiveness were rated on a scale from 1 (very weak) to 9 (very strong). In the result, a brewery, the sum of whose scores was the highest, had the best position.

The diversity of products is the most significant key factor, as diverse products cover a more numerous target audience; consequently, it is possible to increase the number of customers. According to the competitiveness criterion, 'Raiskuma labumu darîtava' Ltd had the highest rating score, as it produced diverse products there. The small brewery introduced a new product - a cherry beer cocktail, which was unique and none of the other breweries had anything like this; it also could reach another segment customers by own smoked meat and own baked bread, thereby popularising its products and

Competitiveness ratings of small breweries selected for the case study

\begin{tabular}{|c|c|c|c|c|c|c|c|c|c|}
\hline \multirow{2}{*}{$\begin{array}{c}\text { Key factors of } \\
\text { competitiveness }\end{array}$} & \multirow{2}{*}{$\begin{array}{c}\text { Weight of key } \\
\text { factors }\end{array}$} & \multicolumn{2}{|c|}{ 'ECOS' Ltd } & \multicolumn{2}{c|}{$\begin{array}{c}\text { 'Odzienas } \\
\text { Pilsbrüzis' Ltd }\end{array}$} & \multicolumn{2}{c|}{$\begin{array}{c}\text { 'Madonas Alus } \\
\text { Darītava' Ltd }\end{array}$} & \multicolumn{2}{c|}{$\begin{array}{c}\text { 'Raiskuma labumu } \\
\text { darîtava' Ltd }\end{array}$} \\
\cline { 3 - 10 } & & Score & $2 * 3$ & Score & $2 * 5$ & Score & $2 * 7$ & Score & $2 * 9$ \\
\hline 1. & 2. & 3. & 4. & 5. & 6. & 7. & 8. & 9. & 10. \\
\hline $\begin{array}{c}\text { Diversity of } \\
\text { products }\end{array}$ & 0.3 & 5 & 1.5 & 7 & 2.1 & 5 & 1.5 & 9 & 2.7 \\
\hline $\begin{array}{c}\text { Tourism } \\
\text { opportunities }\end{array}$ & 0.15 & 8 & 1.2 & 9 & 1.35 & 1 & 0.15 & 5 & 0.75 \\
\hline Extra services & 0.2 & 7 & 1.4 & 9 & 1.8 & 1 & 0.2 & 1 & 0.2 \\
\hline $\begin{array}{c}\text { Financial } \\
\text { situation }\end{array}$ & 0.2 & 5 & 1 & 9 & 1.8 & 2 & 0.4 & 9 & 1.8 \\
\hline Recognition & 0.15 & 7 & 1.05 & 9 & 1.35 & 3 & 0.45 & 1 & 0.15 \\
\hline Total & $\mathbf{1}$ & $\mathbf{3 2}$ & $\mathbf{6 . 1 5}$ & $\mathbf{7 0}$ & $\mathbf{8 . 4}$ & $\mathbf{1 2}$ & $\mathbf{2 . 7}$ & $\mathbf{2 5}$ & $\mathbf{5 . 6}$ \\
\hline
\end{tabular}

Source: authors' compilation. 
contributing to the recognition of the enterprise. 'Odzienas Pilsbrūzis' Ltd produced both alcoholic and non-alcoholic beverages. The beer production technology at 'Odzienas Pilsbrūzis' Ltd was different, as it used more hops that created a bitter taste; for this reason, this beer was popular among those consumers who preferred a bitter taste. The other small breweries dealt only with beer production - 'Madonas Alus Darītava' Ltd made the classical, light 'Baudala' beer, while 'ECOS' Ltd - the light and dark 'Bursh' beer.

Mostly those breweries that were located outside urban areas had opportunities for tourism services. For example, 'Odzienas Pilsbrūzis' Ltd attracted tourists by means of the adjacent manor house, while 'ECOS' Ltd - by means of the River Aiviekste and nature. 'Raiskuma labumu darītava' Ltd was also located outside urban areas, yet it should develop tourism services.

A guest house belonging to 'Odzienas Pilsbrūzis' Ltd and the potential rental of premises in the case of 'ECOS' Ltd, as well as the vicinity of the manor house belonging to 'Odzienas Pilsbrūzis' Ltd and a tradition established by the enterprise - the celebration of the winter and summer solstices and Easter - may be attributed to extra services.

An essential factor influencing competitiveness is the recognition of small breweries in Latvia, which is affected by marketing activities implemented. According to this criterion, 'Raiskuma labumu daritava' Ltd had the lowest score, as it had no enterprise website, while 'Madonas Alus Darītava' Ltd made insignificant activity in social network accounts, which did not contribute to its recognition.

The competitiveness ratings shown in Table 3 allow concluding that 'Madonas Alus Darītava' Ltd had low scores for almost all the key factors of competiveness, which indicated the need to enhance its assortment of products and marketing communication as well as to consider introducing extra services, including tourism.

The products produced by 'Odzienas Pilsbrūzis' Ltd do not directly compete with the products of the randomly selected breweries owing to their taste specifics - the beers have a specific, bitter taste that is preferred by a certain target audience. At the same time, the beer produced by 'ECOS' Ltd has taste nuances, yet, in general, it has the conventional taste of beer. The products and economic performance of 'Madonas Alus Darītava' Ltd and 'ECOS' Ltd are similar. 'Raiskuma labumu darītava' Ltd has developed and enhanced its assortment of products, which gives it advantages in comparison with other breweries.

\section{Conclusions}

1. Most breweries in Latvia qualify for the status of small brewery, including home breweries, the output of which is considerably lower. This means that it is urgent to introduce the status of microbrewery in Latvia, as those home breweries that wish to enter the market and sell their products in small quantities have to undergo the same bureaucratic procedures as larger ones.

2. Even though small breweries operate in the craft segment and their operation differs from that of large ones, yet the small breweries are influenced by the activity of large breweries in the market, which was proved by the decrease in the market share of Aldaris in Latvia in 2014; in the result, the number of new small breweries increased.

3. The brewing industry in Latvia is positively affected by beer drinking traditions, which can contribute to the stable operation and development of small breweries in future.

4. Small breweries have competitive advantages, which contribute to the promotion of their products in the market. It is due to the quality and assortment of their products, as well as extra economic activities, which contribute to the recognition of the enterprises.

5. It is advisable to make further research to determine demand for the craft beers in Latvia, as it can affect the development of small breweries.

\section{References}

1. Aquilani, B., Laureti, T., Poponi, S., \& Secondi, L. (2015). Beer choice and consumption determinants when craft beers are tasted: An exploratory study of consumer preferences. Food Quality and Preference. 41, 214 - 224. DOI: 10.1016/j.foodqual.2014.12.005.

2. Ascher, B. (2012). Global Beer: The Road to Monopoly. Retrieved February 2, 2017, from: http://www. assobirra.it/press/wp-content/ar2012_assobirra1.pdf.

3. AssoBirra (2014). Annual report 2013. Retrieved February 22, 2017, from: http://www.assobirra.it/press/ wp-content/ar2013-assobirra 03-09.pdf.

4. Brager, D., \& Greco, J. (2011, January). Millennials Redefine the Alcoholic Beverage Landscape. Retrieved February 22, 2017, from: http://www.nielsen.com/us/en/insights/news/2011/millennials-redefine-thealcohol-beverage-landscape.html.

5. Bryman, A. (2008). Social Research Methods. Oxford: Oxford University Press.

6. Does beer industry have a future in Latvia (2015). Retrieved February 22, 2017, from: http://www.aldaris. lv/assets/upload/userfiles/files/Aldara\%20prezentacijaPetijums\%20par\%20alus\%20tirgu.pdf. 
7. Donadini, G., Fumi, M.D., Kordialik-Bogacka, E., Maggi, L., Lambri, M., \& Sckokai, P. (2016). Consumer interest in specialty beers in three European markets. Food Research International. 85, 301 - 314. DOI: 10.1016/j.foodres.2016.04.029.

8. Euromonitor International. (2009). Global alcoholic drinks: Beer-opportunities in niche categories. London: Euromonitor International.

9. Euromonitor International. (2014). Beer in Mexico. London: Euromonitor International.

10. Fastigi, M., Esposti, R., Orazi, F., \& Viganò, E. (2015). The irresistible rise of the craft brewing sector in Italy: Can we explain it? Retrieved February 13, 2015, from: http://ageconsearch.umn.edu/bitstream/207271/2/ The\%20irresistible\%20rise\%20of\%20craft\%20breweries\%20in\%20Italy\%20magic\%20out\%20of\%20 nowhere $\% 20$ or $\%$ 20just $\% 20$ another\%20xample\%20of\%20agro-food\%20diversification.pdf.

11. Giacalone, G., Bom Frost, M., Bredie, W.L.P., Pineau, B., Hunter, D.C., Paisley, A.G.P., Beresford, M.K., \& Jaeger, S.R. (2015). Situational appropriateness of beer is influenced by product familiarity. Food Quality and Preference. 39, 16 - 27. DOI: 10.1016/j.foodqual.2014.06.012.

12. Gómez-Corona, C., Lelievre-Desmas, M., Escalona Buendía, H.B., Chollet, S., \& Valentin, D. (2016a). Craft beer representation amongst men in two different cultures. Food Quality and Preference. 53, 19 - 28. DOI: 10.1016/j.foodqual.2016.05.010.

13. Gomez-Corona, C., Escalona-Buendía, H.B., Mauricio, G., Chollet, S., \& Valentin, D. (2016b). Craft vs. industrial: Habits, attitudes and motivations towards beer consumption in Mexico. Appetite. 96, 358 - 367. DOI: $10.1016 /$ j.appet.2015.10.002.

14. Guinard, J.X., Souchard, A., Picot, M., Rogeaux, M., \& Sieffermann, J.M. (1998). Sensory determinants of the thirst-quenching character of beer. Appetite. 31, $101-115$. DOI: 10.1006/appe.1998.0165.

15. Harasym, J., \& Podeszwa, T. (2015). Towards sustainable de-growth e medical survey data as predictors for estimation of niche market value e gluten-free beer market case. Journal of Cleaner Production. 108, 1232 - 1238. DOI: 10.1016/j.jclepro.2015.07.014.

16. Igliński, B., Iglińska, A., Cichosz, M., Kujawski, W., \& Buczkowski, R. (2016). Renewable energy production in the Łódzkie Voivodeship. The PEST analysis of the RES in the voivodeship and in Poland. Renewable and Sustainable Energy Reviews. 58, 737 - 750. DOI: 10.1016/j.rser.2015.12.341.

17. Mejlholm, O., \& Martens, M. (2006). Beer identity in Denmark. Food Quality and Preference. 17 (1-2), 108 - 115. DOI: 10.1016/j.foodqual.2005.10.001.

18. Nield, K., \& Peacock, G. (1995). Competition in the U.K. beer market: further intervention in the U.K. beer market may produce a brand oriented market at the expense of competition and consumer choice. International Journal of Hospitality Management. 14(2), 103 - 106. DOI: 10.1016/0278-4319(95)000155.

19. Riet, J., Sijtsema, S.J., Dagevos, H., \& de Bruijn, G.J. (2011). The importance of habits in eating behaviour. An overview and recommendations for future research. Appetite. 57, 585 - 596. DOI: 10.1016/j. appet.2011.07.010.

20. Stake, R.E. (1995). The Art of Case Study Research. London: New Delhi.

21. Yin, R.K. (2013). Case Study Research: Design and Methods. London: New Delhi. 